\title{
China-Africa exports: Governance through mobility and sojourning
}

\author{
Heidi Østbø Haugen \\ h.o.haugen@ikos.uio.no
}

\begin{abstract}
A centre for Asian and intercontinental immigration and export-oriented production, the city of Guangzhou is at the forefront of China's extroversion. Based on ethnographic fieldwork, this paper examines informal governance mechanisms that coordinate the circulation of goods and capital between China and Africa. The question to be addressed is: What roles do mobility and sojourning play in governing trade relations? The analysis is informed by research from three fields: economics scholarship on the trade-migration nexus, ethnographic studies of informal transborder trade, and historical accounts of long-distance trade in precolonial and colonial eras. These traditions point to different interlinkages between the mobility of people and goods. China's exports to Africa have increased in tandem with the number of visitations by African itinerant traders. The empirical discussion demonstrates that the emergence of intercontinental movements of goods and people between Mainland China and Africa was predicated on the brokering role played by African sojourners in Guangzhou. Of particular importance was informal hospitality and logistics infrastructure set up by Africans in the late 1990s, which has subsequently evolved and adapted to new circumstances. This infrastructure has facilitated the mobility of people and goods and increased the pace at which trading capital circulates.
\end{abstract}

\section{Introduction}

This paper examines how particular patterns of intercontinental mobility and sojourning formed the foundation for, and evolved alongside, the rise in trade from Guangzhou, South China, to African countries. The governance of informal export from China relies both on migrants who provide place-bound infrastructure and the intercontinental mobility of people. African sojourners in China provide trade-related services to the merchants who shuttle between China and their home countries. However, current interlinkages between trade and mobility in Guangzhou are under pressure by the country's increasingly restrictive visa practices. 
The trading economy in South China represents a privileged site from which to study the trade-mobility nexus. The presence of African entrepreneurs in Mainland China is a relatively recent phenomenon, dating back to the second half of the 1990s. The emergence of African business communities in South China must be understood in the context of global migration regimes, under which Europe and North America became less accessible destinations in the 1980s and 90s and traveling to Asia emerged an alternative for would-be African labour migrants. Some of these reinvented themselves as entrepreneurs providing trade-related services in China. Others crossed into the Mainland from Hong Kong, which had been a destination for African traders since the 1980s. Over the past two decades, ChinaAfrica exports and the number of African visitors to Mainland China have increased at the same pace and in closely connected ways.

Interconnectivities between circulations of people, money, and goods have been explored from several methodological vantage points drawing upon statistical, ethnographic, and historical data. The first section of this paper reviews these approaches and their main conclusions. Next, I outline the method of data collection. The analysis in introduced by a synthesis of data on the circulation for goods and people between Mainland China and African countries that provides an overview of emergent patterns. The subsequent, and main, part of the analysis examines how the fixity of some people and the mobility of others in combination structure the governance of exports from Guangzhou to African countries. The first section considers the role of migrant-run hospitality infrastructure in initializing a shift in trade away from Hong Kong towards Mainland China. The second section discusses how informal logistics infrastructure in Guangzhou evolved in ways that were adapted to the economic and social contexts in which the traders operated. The final section examines how itinerant traders combine infrastructures in ways that not only enable their own mobility and the shifting of goods, but also speeds up the pace at which capital is circulated.

\section{The approaches to the study of trade and human mobility}

Three main research traditions address how human mobility patterns condition the governance of international commercial exchange: the economics scholarship on the trade-migration nexus, the ethnographic studies of informal transborder trade, and the historical accounts of infrastructure for long-distance trade in pre-colonial and colonial eras. These approaches foreground different types of relations between trade and human mobility. Although these relations are not necessarily mutually exclusive, the differences in emphasis between the three traditions indicate divergent ideas about how human mobility promotes trade. 
Postprint version. Published text:

https://www.tandfonline.com/doi/full/10.1080/00472336.2018.1517897

\section{Economics scholarship on the trade-migration nexus}

International migration increased from the 1980s onwards. This prompted economists to inquire into the economic consequences of immigration. Their models initially focused on the labour market effects of immigrants. A pioneering study by Gould (1994), however, addressed the implications of immigration for bilateral trade flows, placing the trademigration nexus on the economics research agenda. The study identified two basic ways in which migration enhances trade: first, through the preferences immigrants have for products from their countries of origin, which augments imports, and, second, by lowering information barriers to trade and the risk of opportunism in international exchanges (ibid.). A profusion of economics research have subsequently confirmed that migration exerts a positive effect on trade (Admassu, 2016; Bettin and Turco, 2012; Bowen and Wu, 2013; Egger et al., 2012; Iwanowsky, 2014; Karagöz, 2016; Lin and Yang, 2017; Rauch and Trindade, 2002). Two conclusions from the trade-migration nexus research are of particular relevance for studying trade relations between China and Africa today: The positive effects of migration on trade are exhausted at fairly low levels of migration (Egger et al., 2012), and the trade-migration link is affected by the nature of traded goods, with the effects of migration proving stronger in the case of differentiated goods where migrants lower information barriers (Bettin and Turco, 2012; Hatzigeorgiou and Lodefalk, 2015; Lin and Yang, 2017; Rauch and Trindade, 2002).

How does the information held by immigrants translate into greater trade flows? The trade-migration nexus scholarship highlights the role of immigrant employees in providing information about procurement from their countries of origin to their employers (Gould, 1994: 302). By implication, educated migrants with good employment opportunities have a particularly strong impact on trade (Felbermayr and Toubal, 2012; Hatzigeorgiou and Lodefalk, 2015). This assertion is at odds with the rich sociological literature on ethnic entrepreneurship, which purports that low-skilled migrants have a greater tendency to set up their own businesses and exert direct control over purchasing strategies (Zhou, 2004). Recent economics scholarship attempts to redress this oversight in the trade-migration literature and proposes that the pro-trade effect of migrant networks is, in fact, greater among low-skilled than high-skilled immigrants (Lin and Yang, 2017).

The emphasis on general tendencies in the economics literature neglects how movements of goods and people are shaped by differences in cultural and institutional environments. Formal institutions are generally less effective at enforcing contracts in developing than developed countries. While analyses of large international datasets conclude 
Postprint version. Published text:

https://www.tandfonline.com/doi/full/10.1080/00472336.2018.1517897

that migration stimulates trade by lowering information barriers more than by improving contract enforcement (Egger et al., 2012), this may be different in environments with weak contract laws. Indeed, a study of the trade effects of migration between African countries finds that migrant networks reduce barriers to trade largely by compensating for ineffective formal contractual enforcement (Ehrhart et al., 2014: 3). Similarly, in the case of Chinese business networks in Southeast Asia, the efficiency of these networks in promoting trade is attributed to weak legal environments and the ability of the Chinese networks to deter opportunistic behaviour (Rauch and Trindade, 2002: 129).

The main contribution of the trade-migration nexus scholarship is its firm determination that migration generates opportunities for trade. So far, however, it has treated migration as discrete events, neglecting recent insights from migration research concerning the prevalence of temporary and circular migration, and transnational lifestyles (GCIM, 2005). Furthermore, the economic trade-migration nexus models are based on official records, whereas a large share of global mobility, whether of people or goods, remains unrecorded in government statistics. I now turn to scholarship that predominantly focuses on informal trade relations.

\section{Ethnographic studies of informal commercial importers}

The ethnographic studies of transborder commerce apply a micro-level perspective to identify the interconnections between human mobility and trade. Research on informal commercial importers takes rupture as its starting point. From the early 1990s, a sizable number of studies investigate how people engage in trade to get by in societies undergoing "uncertain transitions" (Burawoy and Verdery, 1999). This coping strategy became common in African countries unsettled by structural adjustment programs, which put conventional livelihoods at risk while producing new opportunities for long-distance trade (Meagher, 2003).

Whereas the economics literature takes migrant numbers and trade volume as its key variables, the scholarship on informal commercial importers focuses on the border itself. A main topic of inquiry is how people and goods get past checkpoints. The expression "suitcase trade" comes from the mode of transporting goods for trade (Freeman, 1997). Alternative terminology emphasizes the means or frequency of travel, such as "shuttle trade" and nonEnglish equivalents (Holzlehner, 2008; Morokvasic, 2004; Holtom, 2006; Yükseker, 2007; Iglicka, 2001), or draws attention to the dubious legal status of cross-border trade, as done in the expressions "informal commercial importers" and "tourist-traders" (Ulysse, 2007; Konstantinov, 1996). 
On some border crossings, authorities enforce limitations on the volume and value of goods that each person is allowed to carry. Traders thus find creative ways to circumvent such restrictions, for instance by under-reporting the value of their goods, asking fellow passengers to wear their merchandise, forging alliances with customs officers, taking advantage of border passes issued to residents in border regions, and traveling at times where the chances of getting pulled aside are smaller (Ellis and MacGaffey, 1997; Holtom, 2006; Konstantinov et al., 1998; Ribeiro, 2009, E., this issue, R., this issue). Some hire people specifically for taking goods across borders. On the border between the Russian Far East and China, for example, where a 50-kilogram baggage weight allowance for tourists was instituted, traders hired Russians as so-called pomogaiki (helpers) or kemely (camels) to take their goods across the border (Holzlehner, 2008). Attempts to regulate border trade give rise to informal economic systems to avoid such restrictions, which in turn may be perceived as a threat to the prevailing social order. Local jargon for transnational small-scale traders can therefore be rich in expression with negative connotations. For instance, Russian shuttle traders who traveled to China after 1991 became known as "hoovers" because of their alleged willingness to buy all kinds of goods, regardless of quality (Humphrey, 1999).

The trade-migration nexus scholarship highlights that migrants can enforce agreements across political jurisdictions and in the absence of effective protection of contractual rights. However, the concrete ways through which migrants ground trust and contribute to contract enforcement by and large remains a black box in economics. The ethnographic scholarship highlights that trust does not automatically follow from shared national origin and kinship ties: The advantages of knowing someone personally must be weighed against the obligations that come with such bonds. Some traders attempt to minimize the risks and consequences of opportunism by keeping business relationships within the family. However, family members and kin may feel entitled to take money out of the business for their own needs. In societies where the notion of individual property is ambiguous within kin groups, seizing funds from the businesses of kin to cover expenses for family emergencies can be socially acceptable (Rubbers, 2009). Employing strangers may therefore be preferable to hiring relatives, as it helps to separate business and social relations and creates more opportunities to sanction the abuse of trust (Humphrey, 1999; Hart, 2005). Common adherence to non-state institutions, such as religious societies, may also offer protection against opportunism. In the Mouride Islamic order, for example, enforceable trust and 
reciprocal relationships among members has constituted a resource for Senegalese traders in Asia, Europe, and the United States (Ebin, 1993; Peraldi, 1999).

\section{Historical accounts of hosts and long-distance traders}

While the research about informal commercial importers approaches economic exchanges from the vantage point of the border, the historical literature on long-distance trade in precolonial and colonial times focuses on the place-bound infrastructure in commercial centres that makes the mobility of traders possible. Rich accounts of brokerage in West African Hausa and Mandinka trading networks document how the presence of co-ethnic resident hosts allows traders to traverse large distances. The host was a "settled stranger" in the city of residence and depended on relationships with visiting traders to retain the status as host (Launay, 1979: 76). The host-trader relationship was traditionally associated with trade in livestock and kola but by late colonial times was used by traders of a wide range of storable products (Hill, 1966).

The host assisted the visitor in buying, selling, and storing goods, and was directly or indirectly involved in trade (Launay, 1979). The involvement ranged from operating as an intermediary in transactions in the market to turning one's compound into a wholesale market from where traders could sell their wares and have a one-stop outlet to stock up on goods (Hill, 1966: 350). Hosts provided food and accommodation free of charge, and the host-trader relationship was marked by moral obligation as much as commerce. The remuneration the host received often came through indirect paths, for example via commissions charged from local business people on deals brokered with the visiting traders.

The identity as strangers could be retained for several generations after people settled in a new place and started hosting visiting traders (Cohen, 1965). The relationships developed over time with local populations were indeed how hosts could provide the traders with useful services (Pellow, 2002). It was not the host's status as a migrant in itself that made him (in the studies quoted, hosts were always men) useful to the itinerant traders but rather his ability to mediate between individuals and groups. This suggests that the focus on migrants in the trademigration nexus scholarship could be extended to include second- and third-generation immigrants. That settled strangers greatly affected trade patterns confirms the conclusion in the migration-trade nexus literature about the potential impact of small groups of migrants. 


\section{Method}

The analysis in this paper is informed by data from 16 months of ethnographic fieldwork among African residents and visiting traders in Guangzhou, carried out between 2009 and 2017. My approach was multi-sited: I "followed the things" (Marcus, 1995) through various stages in the production and distribution processes. The point of departure for the fieldwork was the neighbourhood of Xiaobei in Guangzhou, where wholesale outlets, logistics offices, hotels, guest houses, and restaurants catering to African traders were clustered. Alongside African business people, I travelled to the factories where the goods for export were produced and the warehouses from where they were shipped. Short fieldwork periods in Nigeria, Ghana, the Gambia, and Togo allowed me to reconnect with traders and follow distributors on the African end of the value chains.

The main method of data collection was participant observation, complemented by semi-structured interviews and analyses of policy documents and media reports. Participant observation allowed me to collect data on sequences of events without relying on retrospective narration from research participants, which were often poor in detail. Mandarin Chinese was the lingua franca among the Chinese research participants, most of whom originated from outside of Guangzhou, where the native dialect is Cantonese. I conducted the fieldwork in Mandarin, English, and French.

\section{New patterns of circulation}

The patterns of circulation of goods, money, and people between Mainland China and African countries have changed dramatically over the past two decades. This section presents some main trends in the cross-border movement of goods and people, providing context for analysing the governance structures that have developed in response to, and enabled, these transformations.

\section{Trade from Mainland China to African countries}

China overtook the United States as Africa's most important trading partner in 2010, following two decades of sustained growth in officially recorded trade and other forms of economic interaction between China and African countries (AfDB/OECD, 2010). The spatial patterns of these trade flows are highly uneven: Chinese imports are mainly sourced from a few resource-rich African nations, while the size of Chinese exports to various African countries effectively reflects population size and GDP per capita (UN Comtrade, 2016; UNDP, 2017). The value and composition of Chinese exports to African countries are 
notoriously difficult to ascertain due to problems of under-reporting, under-invoicing, misclassification of goods, and misattributing of the country of origin and destination, means through which traders reduce costs of customs clearance and circumvent import bans (Haugen, 2011).

Alongside the growth in the aggregate volumes of Sino-African trade, which has received ample attention from policy-makers and academics across the world, a less noted shift transpired: Goods were increasingly exported directly from Mainland China to African countries rather than passing through Hong Kong. The trend is documented by time series data from the United Nations' (UN) Comtrade database, which records bilateral trade by value: In 1995, 60 percent of all exports from China to Sub-Saharan Africa originated in or were routed through Hong Kong. The corresponding statistic in 2015 was eight percent, whereas 17 percent of all Chinese exports were made in or re-exported via Hong Kong (UN Comtrade, 2016).

Information about shipping volume provides a useful supplement to data on trade value. Measuring trade by 20 -foot container equivalent units (TEU) has the advantage of including all sea-carried trade, whether or not the goods clear customs properly. Statistics of container traffic reveals the same trend as data on trade volumes: a declining share of trade from China to Africa that originates in or passes through Hong Kong. The trend is illustrated by Figure 1, which shows that the number of containers shipped from Mainland China to Africa has increased substantially since the year 2000, whereas the amount of containers shipped from Hong Kong to Africa has stagnated. In short, Chinese exports are reaching African countries through increasingly direct routes, bypassing the entrepôt of Hong Kong (for a discussion of Hong Kong as an entrepôt state, see H\&N, this issue). 


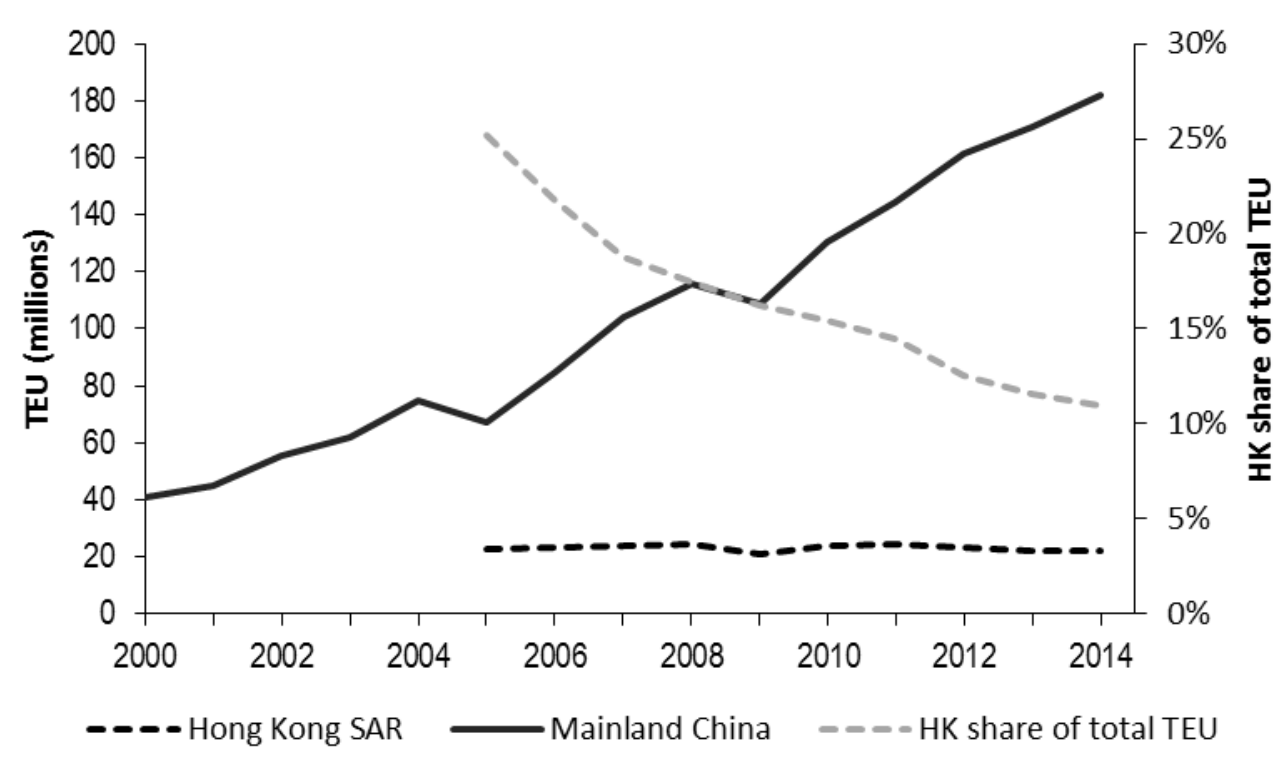

Figure 1: The container port traffic from Mainland China and Hong Kong Special Administrative Region ports, 2000-2014, in million 20-foot equivalent units (TEU) per year.

Source: Data from the World Bank (2017) Container Port Traffic Database. Data for Hong Kong only available after 2005.

Guangdong Province was a pioneer in attracting foreign manufacturing investment and expertise, and was the production site for much of the China-made merchandise reexported through Hong Kong (Cartier, 2001). The symbiotic relationship between Hong Kong and the rest of the Pearl River Delta was labelled "front shop, back factory" (Sit, 1998): Coordination, trade, transport, and financial services were concentrated in Hong Kong, while labour-intensive and polluting production was located in Mainland China. Large-scale investment in the expansion of logistics infrastructure was essential in creating the possibility to export directly from Guangdong to the rest of the world. Shenzhen opened a deep-water port in 1994, which has become one of the world's busiest ports (Liu et al., 2013). The Port of Guangzhou subsequently expanded with a Nansha deep-water terminal and the Huangpu New Terminal. The planned investment of billions of yuan will further develop the physical, legal, and financial infrastructure for trade in Guangdong (Zhang, 2015). As noted in K.'s (this issue) analysis of trade in and through Central Asia, the state facilitates informal commerce through the erection of shipping infrastructure. For the growing trade between Mainland China and Africa, however, the surge in migration and human mobility in both directions was as important as the establishment of formal infrastructure for trade. The provincial capital of Guangzhou, located upstream from Hong Kong in the Pearl River Delta, emerged as the centre for African business people in China, as discussed in the next section. 
Postprint version. Published text:

https://www.tandfonline.com/doi/full/10.1080/00472336.2018.1517897

\section{African visitors and sojourners in Guangzhou}

The mobility of people from Africa to China is nothing new. Ever since the founding of the People's Republic of China, a steady stream of diplomats, students, and official delegations have been invited by Beijing, with the exception of a few years during the cultural revolution (Dikötter, 1994; Gillespie, 2001; Hevi, 1963; Snow, 1988). Today, Africans are visiting China in unprecedented numbers, and most come at their own initiative rather than as official guests. Between 1995 and 2015, the number of entries into China by nationals of African countries saw a 14-fold increase and currently stands at 580,000 person-times (National Bureau of Statistics of China, 2016). Most of these are arrivals into Guangdong Province, either overland via Hong Kong and Macao, or through Guangzhou's Baiyun Airport (Ping, 2014).

As African visitors and residents began to constitute a large and visible minority in certain neighbourhoods of Guangzhou, popular demands to regulate immigration from African countries grew. Well-publicized cases of foreign drug traffickers as well as worries about the lack of means to govern populations of undocumented immigrants generated political pressures for immigration reform both at local and national level (Chinese People's Political Conference 2008). Riots among Africans in Guangzhou further aggravated concerns that immigration constituted a threat to social stability in the region (Yan 2012). The first comprehensive immigration legislation in China - the Exit and Entry Administration Law took full effect 1 July 2013 (Ministry of Public Security 2012). The restrictions formalized by the new law, combined with more rigorous visa requirements put in place by Chinese embassies in Africa, have made entry to China more difficult and expensive, much to the lament of business owners in China who depend on customers from Africa

The number of visits by Africans to China has increased at about the same rate as exports from China to Africa for the past 20 years, as illustrated by Figure 2. In 2008, the value of exports to Africa decreased temporarily due to price drops caused by the global financial crisis. The dip in the number of entries by Africans from 2014 to 2015 can be attributed to more stringent visa policies following the Ebola outbreak in West Africa and the general tightening of immigration control discussed above. Chinese administrative reforms designed to exert stronger control over visa issuance have increased the costs of traveling to China for everyone. In 2017, traders who have gone back and forth to China to purchase goods for more than a decade reported that the costs of obtaining visas through official channels has reached CNY 4,000 . 


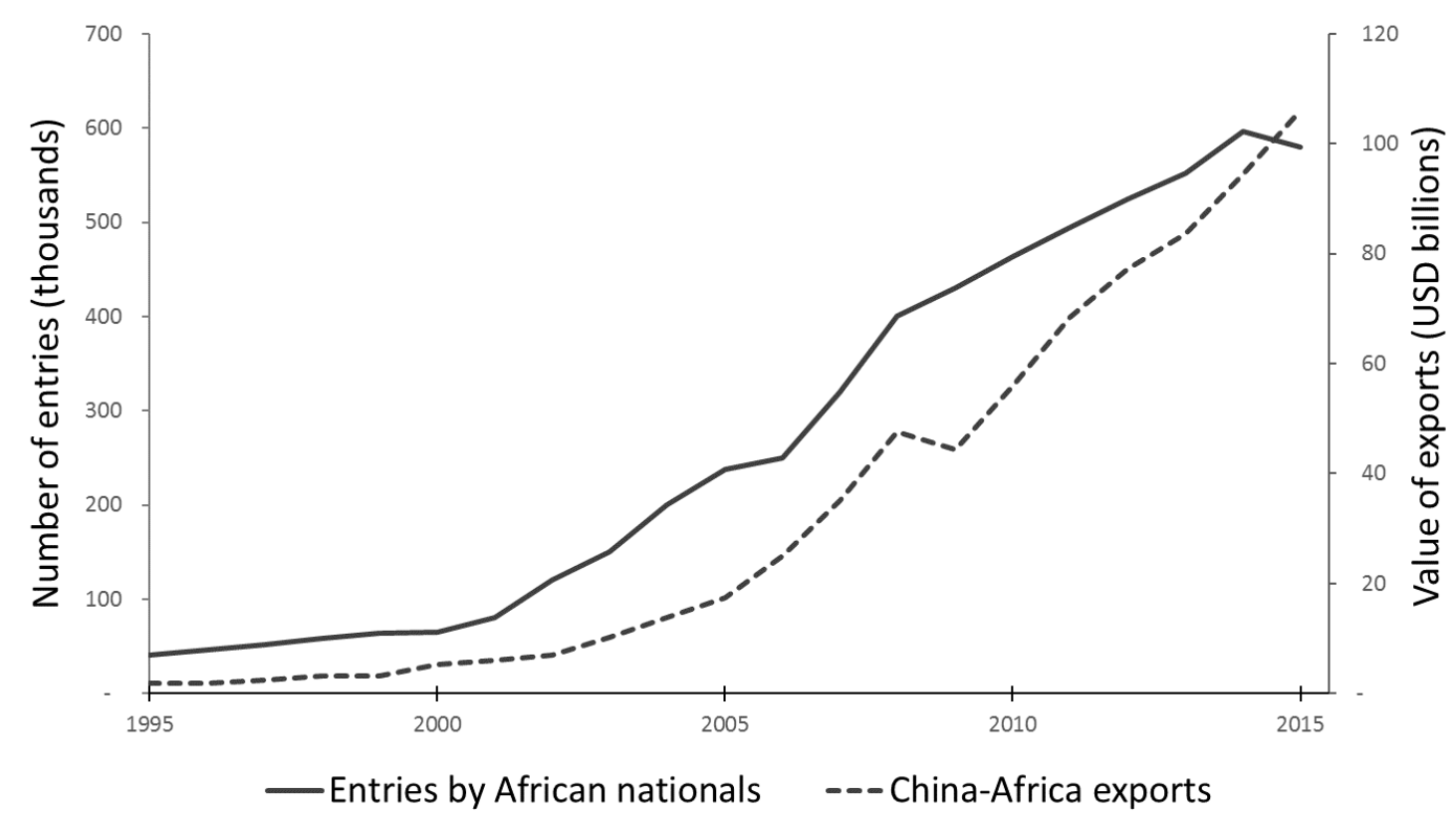

Figure 2: The number of entries by African nationals to China and the value of Chinese exports to Africa.

Source: The National Bureau of Statistics of China (2016) and the UN Comtrade Database (2016). The numbers of entries are interpolated for missing years.

The number of Africans who reside in Guangzhou long-term is much lower than the entry count. Guangzhou officials put the number of African residents in the city at around 16,000 in 2014 (Ping, 2014). This figure is based on residence records and omits both undocumented migrants and Africans living in the greater Guangzhou metropolitan area. Undocumented African migrants have increasingly moved out of Guangzhou to escape the city's exceptionally hostile environment for undocumented migrants, including frequent visa controls in public spaces and apartment buildings. A survey using respondent-driven sampling (RDS), a statistical method designed to appraise hidden populations, estimated that about 39 percent of the Africans living in Guangzhou were undocumented in 2012 (Liang, 2013).

Combined data from residence records and the survey puts the total population of Africans in the city of Guangzhou at approximately 22,000 persons, a low figure compared to the hundreds of thousands of Chinese nationals living in African countries (Mohan et al., 2014). A report released by the Guangzhou Municipal Public Security Bureau in February 2017 announced that 10,344 Africans were officially registered as residents in the city, the lowest value in recent years and an indication that Guangzhou's efforts to push Africans out towards other parts of the Pearl River Delta were effective (China News Service, 2017). 


\section{Governing the circulation of people, goods, and money: Migrant-run infrastructure for trade}

The first African to settle and establish businesses in Guangzhou came into Mainland China from Hong Kong. Today, most African traders bypass Hong Kong altogether, arriving through the multiple direct airline routes from Africa and the Middle East to Guangzhou. A decade of qualitative studies document the central role of physical visits to China to the business model of African traders (Bredeloup, 2012; Bodomo, 2010; Haugen, 2011; Le Bail, 2009; Lyons et al., 2008; Li et al., 2009; Mathews, 2016; Castillo, 2014). The analysis below elaborates on the interrelated topics of how different types of mobility are interlinked and how the fixity of some (African sojourners in China) enables the mobility of others (African itinerant traders). Various forms of mobility come together and form the basis for the governance of movement of goods from factories and trading malls in Guangdong to end markets in Africa.

\section{The migrant-run hospitality infrastructure}

The arrival of African traders in Guangzhou in the mid-1990s represented a spatial extension and redirection of existing trade routes. Some African traders purchased goods in Hong Kong as early as the 1970s (Bertoncello and Bredeloup, 2007), but by the mid-1990s, traders from a range of African countries were traveling to Hong Kong and other far-away trade hubs, such as Istanbul, Dubai, and Bangkok (Bredeloup, 2012; Darkwah, 2002; MacGaffey and Bazenguissa-Ganga, 2000; Meagher, 2010; Verne, 2012). The average mark-up for goods reexported via Hong Kong was as high as 24 percent at the time (Feenstra and Hanson, 2004), suggesting that the potential benefits of dealing directly with the factories in Mainland China were significant. Why, then, were goods procured in Hong Kong rather than Mainland China for such a long period?

Accounts from African traders who crossed the border from Hong Kong to Mainland China in the late 1990s indicate that they regarded the venture as risky and unsettling. Hong Kong was a busy city, yet the urban landscape was legible and easy to navigate. In Mainland China, by contrast, even meeting one's basic needs was challenging and locating suitable manufacturers even more so. This bewilderment is difficult to imagine today, as the streets of busy trading districts are lined with cheap Chinese-run hotels, displaying information in English, French, and Portuguese, and restaurants serve Halal food and African staples such as plantains, fried fish, and Jollof rice. 
The establishment of an informal, migrant-run hospitality infrastructure in Guangzhou made Mainland China more accessible to African itinerant traders. Much like in the historical host-trader relationships described in the literature review, the hosts in Guangzhou often doubled as procuring agents and their relationships with visiting traders were marked by both social and moral obligations, and commercial considerations. Hosts were expected to cook for their guests and to act as their personal assistants when they, for example, needed to see a doctor, make travel arrangements, or place international phone calls. Catering to the traders' needs could be time-consuming and stressful, but it also strengthened the traders' bonds to their hosts. An East African university student in Guangzhou, whose student visa enabled him to rent an apartment in which he hosted visiting traders, explained that he would miss classes to help his guests if necessary. As long as he provided them with everything they needed during their stay in China, they would have few chances to meet competing hosts or to figure out how to find their way around themselves. In other words, ensuring that guests were content was a way to simultaneously fulfil cultural expectations and to protect one's business interests.

The first African sojourners in Guangzhou who hosted itinerant traders earned generous commissions from placing their guests in contact with local suppliers. They commonly charged a commission both from the African traders and the Chinese suppliers on the deals they brokered. The commissions could amount to ten percent of the total value of the deals. Hosts collected commissions from the traders according to pre-determined rates as they went along or received a lump sum ("a dash" in West African pidgin) at the end of the traders' stays. Commissions from suppliers were often collected unbeknownst to the traders. When hosts brought traders to a supplier, the supplier included the fees they charged in the prices they quoted to traders. The hosts would later return without the traders to collect their commissions.

The strong tradition for combining the roles of host and intermediary in long-distance trade in parts of Africa provided the cultural basis for the business model in which hospitality was transformed into profits. However, unlike in the historical trade in livestock and kola, traders visiting Guangzhou could disconnect themselves from their hosts by engaging in unmediated relationships with suppliers. In other words, the host-trader relationships in Guangzhou were much more fragile than those described in the historical accounts from West Africa. Hosts employed a variety of strategies to prevent traders from contacting suppliers on their own. An Igbo Nigerian who went by the name of Prince and arrived in China in 2001 
reminisced about the profits he made from being a go-between during his first years in China. He invited traders from Nigeria and other African countries to live in his apartment during their visits to Guangzhou. The apartment doubled as a showroom and was filled with product samples and catalogues from factories. Prince made sure to remove any contact information from the promotional material to prevent the traders from getting in touch with producers on their own. The traders would eventually find ways to cut him out of their deals but the precautionary measures prolonged their dependence on him.

Although traders became more familiar with the business environment in Guangzhou and less ready to retain sojourners as go-betweens, informal guest houses ran by African migrants prevailed. The hosts started collecting lodging fees rather than relying on indirect payments through commissions. In 2014, the daily rent for this type of accommodation typically ranged between CNY 50 and 120 per night. Other hosts charged a flat rate for the entire stay, which could vary from a few days to several weeks. The cheap and flexible lodging suited the traders, who often arrived with open return tickets and stayed for as long as it took to complete their purchases. Yet, some preferred the more expensive formal hotels. One reason was privacy: Cut-throat competition between traders had turned information into a valuable asset and successful traders started to worry that fellow lodgers would look through their goods to copy their business ideas.

Once traders shifted towards hotels, African sojourners found new ways of reaching potential customers. Chinese hotel managers notified African partners when guests from their home countries or linguistic regions arrived. This enabled providers of trade-related services to get in touch with potential customers. The hotel managers received token payments for the favours and kickbacks if the information they provided generated business. By sharing their proceeds with Chinese hotel owners, some Africans living in Guangzhou could enjoy certain benefits of hosting without actually accommodating traders in their homes.

\section{The informal logistics infrastructure}

Logistics were the main bottleneck in China-Africa exports in the late 1990s. Unless traders had enough capital to ship full containers of goods from a single factory, their merchandise was still transported out of China via Hong Kong. No shipping agents in Mainland China offered so-called "groupage," containers shared by several customers who each paid for the volume they occupied. Groupage allows traders with limited capital ship goods inexpensively. In fact, some traders with more than enough money to send full containers prefer groupage to mitigate the risk of loss and allow their wares to reach the market at different times. The first 
logistics agencies offering groupage directly from Mainland China were Nigerian-Chinese joint ventures. By allowing goods to bypass Hong Kong, the groupage providers had a profound impact on trade routes.

Traders in Guangzhou have six main ways of moving goods to Africa: full containers, groupage, air cargo, formal courier services (such as DHL and UPS), bringing goods on planes as luggage, and "hand carry" services. The latter is an informal alternative to global courier companies. Travelers who do not intend to use their luggage allowance sell it to logistics brokers. The brokers collect goods from customers, pack them, and deliver them to the traveller at Baiyun Airport when he or she is checking in. Once the traveller reaches the destination, the goods are handed over to the broker's representative on the African side, from whom their owners can pick them up. In Nigeria, the logistics agencies have partners inside the airport who extricate the goods directly from the cargo area. Hand carry is not only used for exports from China but also to carry vital business items such as contracts, release documents for containers, and pre-production samples.

The responsibilities of logistics companies extend beyond the physical movement of goods from one place to another by air or sea. Equally, if not more, important is customs clearance, both on the Chinese and African end. In theory, logistics brokers are required to be formally registered as companies and have licenses to clear customs. In practice, however, many pay licensed brokers to lodge declarations in their name. Skilled logistics brokers change the paths through which they move goods, as control routines, informally and formally levied fees, and import bans change at various points of entry. Experience enables them to accurately predict the fees associated with bringing both legal and contraband goods to their destinations. Yet, unanticipated events may arise, leading to conflicts over responsibility and compensation. Traders often prefer to remain with the same logistics broker to have a stronger moral claim in such situations. Goods that get trapped in customs can ruin a trader's business, and traders may look as much to credibility as to price when they select logistics providers. Besides ensuring that goods reach their destinations safely, logistics agents may take on some of the same roles as the hosts described in the previous section, helping their clients to resolve practical problems and manage relationships with Chinese suppliers. The term "cultural broker" has been applied to describe the emotional and relational work undertaken by resident Africans who assist visiting traders in navigating the social environment in Guangzhou (Mathews, 2016). 
Traders may personally deliver goods to the warehouses of logistics agents. More commonly, however, they instruct factories to bring their orders to their logistics agent's warehouse. Logistics agents notify customers when their orders are delivered. The process puts the logistics agent in an exposed position in the case of disputes. Negotiating such situations requires experience and the trust of both parties. An incidence at the warehouse of a Kenyan logistics agent provides a case in point. The owner of a jeans factory came rushing into his warehouse with three other men. The factory had delivered goods for shipment but the customer had not paid as agreed. The manufacturer wanted the merchandise back and was prepared to use physical force if needed. The logistics agent asked them to wait. Whether it was his calm and respectful demeanour or their longstanding relationship that convinced him, the factory owner let the logistics agent try to work it out. The logistics agent got hold of his customer, who promised to pay shortly. The manufacturer was persuaded to leave the goods in the logistics agent's custody in the meantime. Once the factory confirmed that the payment had been completed, the goods were loaded for shipment.

Profit creation is contingent on the circulation of capital. There is an inherent inertia in ocean container shipment: The containers must load, spend weeks at sea, unload, and go through customs clearance. In the meantime, the trader's capital is tied up; "the money is not moving," as one Ghanaian trader put it. Thus, keeping delivery times down is key to a successful logistics business. Only large logistics providers have enough customers to ship one or more 40-foot containers per day. "The way we load demands customers," a Chinese partner in a large logistics company explains. "If you let the goods stay in the warehouse, you load slowly." Her agency now ships around 1,000 containers per year. Newly established logistics agencies try to undercut her but struggle to maintain competitive delivery times because they have to wait to amass enough goods to fill a container.

Besides loading time, unloading and customs clearance on the African end of the shipment route are the largest sources of delays. Apapa Port outside of Lagos, for example, has a famously long dwell time for incoming containers. A multitude of government agencies are present at the port, and numerous approval processes can cause extensive waits. To abate the problem, ten federal agencies were removed from Nigerian ports in 2011 and charges were raised to prevent logistics companies from using the port for storage (Port Strategy, 2011). Yet, the effectiveness of the local clearing agent in navigating formal and informal processes in the ports is still the main determinant of how quickly containers are released 
Postprint version. Published text:

https://www.tandfonline.com/doi/full/10.1080/00472336.2018.1517897

from customs. Logistics and clearing agents together find creative ways to circumvent import bans and minimize customs expenses.

\section{Double-looped capital circulation}

Planes arriving at Baiyun Airport from Addis Abeba, Istanbul, or Qatar carry passengers from across Africa. Those who are visibly disoriented as they exit from customs are approached by Chinese drivers and African trading agents. However, most have made the trip to Guangzhou several times before and swiftly make their way to the bus, subway, or taxi stops. To prepare for these journeys, African traders must collect enough money to make the travel costs worthwhile. Some bring only USD 10,000, others more than USD 100,000. Regardless of how much they have at their disposal, they are determined to make the most of their money. As we see in this section, migrant-run infrastructure enables traders to circulate their capital more efficiently.

Marie-Claude, a Congolese trader in her 30s whose main business is importing children's clothes and shoes from China, stayed in a guesthouse a few floors up from where I resided in Xiaobei. A man from Kinshasa was in charge of the apartment, and he asked for USD 100 from every guest regardless of the length of their stay. The apartment was overcrowded with goods and people, and was stiflingly hot in the summer, but the flexibility combined with predictably low accommodation costs made up for the inconvenience. The host was away most of the time, and the tenants took turns cooking with ingredients they brought with them from Kinshasa: leaves, pulses, tubers, and dried fish.

Like other African traders in Guangzhou, Marie-Claude spends her days in various trading outlets spread around the city. She once hired a Congolese man to show her around the markets for children's clothes, jewellery, and mobile phones, and made sure to memorize the public transport routes and take name cards from shops to be able to go back on her own. She orders goods with a low value-to-weight ratio to be delivered to the warehouse of the Congolese groupage shipment agent. The goods shipped by sea included furniture and women's clothes that are not sensitive to fashion. Sitting down with the wholesaler, she gives precise descriptions about sizes, colours, and styles, and then makes a down payment to confirm the order. However, most of her time is spent carefully selecting fashion items that she packs in suitcases and brings with her when she travels home.

Transcontinental suitcase trade has a long and well-documented history in the Congo, dating back to the 1980s, when Congolese air hostesses and other highly mobile people carried foodstuffs to migrants in Paris and brought fashion goods back to sell in the capitals of 
Kinshasa and Brazzaville (MacGaffey and Bazenguissa-Ganga, 2000). Congolese travelers brought goods into the country under the pretence that they were carrying personal items. Passenger airlines let Congolese travellers bring up to 13 additional pieces of luggage of 32 $\mathrm{kg}$ on their return trips from Guangzhou. These cost USD 220 per unit in 2014, which is considerably more expensive than container shipment but cheaper than regular air cargo. The large amount of goods carried by the traders notwithstanding, customs officers would go along with the make-believe as long as the goods were packed in suitcases. Congolese traders therefore bought cheap suitcases in China for the sole purpose of transporting goods through customs. As in the case of suitcase traders in the early 1990s, the transport of goods across borders succeeds due to a combination of individual creativity and informal collusion between small-scale traders and customs officers.

By combining groupage and air transport, traders can circulate their capital in a double loop every time they travel to China. Once the traders reach home, they start selling off the goods carried in suitcases. The money they collect is remitted to the suppliers of merchandise for container shipment. The supplier may receive money via regular bank transfer or through one of the many informal money transmission agencies set up by African migrants in Guangzhou. Once they are paid, the suppliers proceed to deliver the goods to logistics agents as instructed by the trader. The agents pack the merchandise, and while the goods are at sea, the trader attempts to sell off the rest of the air-carried goods. When the container reaches the trader's place of residence, the merchandise it holds is sold as well. With the capital back in the traders' possession, he or she can travel to Guangzhou again and put the money back into circulation.

Fast transactions generate profit but also spawn risk. In their eagerness to increase turnover and ensure that time-sensitive products reach their markets, suppliers as well as logistics agents may extend credit that is never reimbursed (Haugen, 2017). Logistics agents who offer credit to their customers must be particularly careful to pace the deliveries. Some customers are permitted to collect their goods before reimbursing the logistics agent. The trader sells some of the goods before paying the freight. "At each given time, your customer owes you money," a groupage agent who operates out of Nairobi's business suburb of Eastleigh said. "This is not a problem as long as they keep sending goods. But if they stop, you have a problem!" He considers it fair to allow the traders up to four weeks after they collect their goods before repaying him. If they fail to reimburse debts, however, he may retain their next shipment batch as security. This guarantee is useless if the customer 
discontinues the trade, in which case the logistics agent relies on moral arguments, social sanctions, or outright threats to get the money back. Some traders change logistics agents to sidestep debts. For example, a Nigerian logistics provider based in a Guangzhou trading mall caught a customer who owed him money sending goods with a competitor. He shouted at the trader and started beating him when he refused to pay his debts. Such occurrences are so commonplace that people in neighbouring shops barely noticed the drama.

Migrant-run trading infrastructure in Guangzhou represents an adaptation to a specific business environment, where traders have limited capital, formal contract enforcement is weak, the social pressure for redistribution is strong, and the political and economic environments are volatile. The infrastructure fits the social circumstances the traders operate within. This is illustrated through the example of groupage shipping, which traders employ partly to manage pressures to redistribute wealth. Patron-client relationships, with their associated expectations for redistribution, are important across post-colonial Africa (Berman, 1998). Traders must balance the pressure to provide for others with the need to keep their capital tied up in productive investments.

\section{Discussion and conclusion}

Chinese exports to African countries have increased greatly over the past two decades, with a parallel growth in the number of traders visiting China. The structures set up by African sojourners in Guangzhou allow these traders to engage in activities that are variously classified as formal, informal, and illegal by the state. This infrastructure replicates structures set up in other places or earlier periods, but has also been modified to serve trade that is intercontinental and based on both container and air transport. Air travel and the introduction of new direct flight routes between Baiyun Airport in Guangzhou and African airports have speeded up the circulation of both goods and people. The combination of air cargo and a flexible low-end manufacturing sector in South China has reduced the time from the design of new products to production and distribution in African end markets to few weeks for fashion sensitive goods. The pace of supply chain capitalism (cf. Tsing, 2009) is no less breath taking in South-South transactions than along the value chains of large multinational companies.

As China stands at a critical juncture in its strategy for managing immigration, the main conclusion from economics scholarship on the trade-migration nexus - that immigration promotes exports- has high policy relevance. A key insight from the current study is that the temporal dimension ought to be included as a variable in analyses of the trade-migration nexus. In the two decades of history of African trading communities in Guangzhou, the ways 
in which migrants support the commercial activities of itinerant traders have evolved greatly, which suggests that the duration of commercial contact and immigration affect the nature of the links between trade and migration. African traders have become more independent in their dealings with Chinese suppliers, and Chinese entrepreneurs and African sojourners who provide services for visiting traders often operate in competition with each other.

Furthermore, the assertion that the trade effect of migration is exhausted at fairly low levels of migration is called into question by the Guangzhou experience. Although migrants find it more difficult than before to make money from providing services to itinerant traders, new migrants continue to identify niches in which to make money from trade. Manufacturing in the Pearl River Delta is extremely diverse in terms of both product types and qualities, and the range of products imported by African traders is still expanding. For migrants arriving with specific industry knowledge and contact networks among procurers, there are still opportunities to be discovered and exploited.

Ethnographic studies of informal trade, whether in Guangzhou or other parts of the world, have documented the great creativity with which African traders operate and the culturally and spatially contingent ways in which trade and mobility are connected. The recent emergence of mobile methods and ethnographies set in transnational fields has contributed to better understanding of the role of mobility in economic ventures and identity formation more generally. Such ethnographic studies furthermore highlight the devastating impact immobility can have on economic futures. Ethnographic studies of trade and migration in both directions between China and African countries have proliferated in the past decade, and provided much-needed insight into Sino-African relations from the perspective of the people involved. To avoid the trap of exceptionalism, studies of trade between China and Africa should be informed by analytical insights from research in other contexts and aim to move scholarship on informal trade forward. One way of advancing this scholarship would be through comparative studies of place-bound infrastructure for trade, whether managed by locals or migrants.

Historical accounts of relationships between hosts and itinerant traders describe the antecedents and cultural context of some of the infrastructure run by African migrants in Guangzhou today. Rich descriptions of how trade in Africa has been organized in earlier eras serve as reminders that the current trade with China represents, in part, a spatial extension of long-standing trading networks. For traders whose commercial life date back several generations, Guangzhou is but the most recent node in a system of places with commercial 
opportunities. The literature on historical trade networks raises a question that will become relevant in future research on African migrants in Guangzhou: When the children of African parents who are born and grow up in China become adults, will they also serve as links between visiting traders and their host society? The answer to this question depends on a variety of dynamics, including whether China retains its position as a supplier of cheap manufactured products, restrictions on transnational mobility, and the political and social space for non-ethnic Chinese to remain and thrive in the country. The reactions to the 2014 Ebola outbreak highlight that to many Chinese, the inflow of people from faraway places primarily represents a threat. Insights into the opportunities presented by immigration are important counter-narratives to discourses that portray immigration as a problem. As China is about to implement its first comprehensive immigration policy, such correctives are more important than ever.

\section{References}

Admassu S. (2016) A Comparative Analysis of African and Asian Migrants' Effect on Trade. http://www.freit.org/WorkingPapers/Papers/Immigration/FREIT1103.pdf (accessed 15.04.2017).

AfDB/OECD. (2010) African Economic Outlook 2010. Tunis: African Development Bank \& Organisation for Economic Co-operation and Development. http://books.google.no/books?id=RnAKI609pQoC\&printsec=frontcover\&hl=en\#v=on epage $\& \mathrm{q}=$ china $\& \mathrm{f}=$ false $($ accessed 10.05.2017).

Berman BJ. (1998) Ethnicity, patronage and the African state: the politics of uncivil nationalism. African Affairs 97: 305-341.

Bertoncello B and Bredeloup S. (2007) The emergence of new African "Trading Posts" in Hong Kong and Guangzhou. China Perspectives 6: 94-105.

Bettin G and Turco AL. (2012) A cross-country view on south-north migration and trade: dissecting the channels. Emerging Markets Finance and Trade 48: 4-29.

Bodomo A. (2010) The African Trading Community in Guangzhou: An Emerging Bridge for Africa-China Relations. The China Quarterly 203: 693-707.

Bowen HP and Wu JP. (2013) Immigrant specificity and the relationship between trade and immigration: theory and evidence. Southern economic journal 80: 366-384.

Bredeloup S. (2012) African trading post in Guangzhou: emergent or recurrent commercial form? African Diaspora 5: 27-50.

Burawoy M and Verdery K. (1999) Uncertain transition: Ethnographies of change in the postsocialist world. Lanham, Md.: Rowman \& Littlefield.

Cartier C. (2001) Globalizing South China, Oxford: Blackwell.

Castillo R. (2014) Feeling at home in the "Chocolate City": an exploration of place-making practices and structures of belonging amongst Africans in Guangzhou. Inter-Asia Cultural Studies 15: 235-257.

Chinese People's Political Consultative Conference (2008) 从出租屋管理入手加强对在穗居 留外国人的管理 (Strengthening the management of foreigners living in rented houses in Guangzhou) 
http://www.gzzx.gov.cn/lunzheng/content.aspx?id=633391252806005078442 (accessed 01.02.2010).

China News Service. (2017) 在广州实有非洲国家人员降至 10344 人(There are 10344 residents from African countries in Guangzhou). (accessed 15.04.2017).

Cohen A. (1965) The Social Organization of Credit in a West African Cattle Market. Africa: Journal of the International African Institute 35: 8-20.

Darkwah A. (2002) Going global: Ghanaian female transnational traders in an era of globalization (PhD Dissertation), Madison: University of Wisconsin-Madison.

Dikötter F. (1994) Racial Identities in China: Context and Meaning. The China Quarterly: 404-412.

E. (this issue) Navigating Small-Scale Trade Across Local Thai and Lao Checkpoints: The Role of Legitimacy, Social Relations, And Money.

Ebin V. (1993) Les commerçants mourides à Marseille et à New York. In: Grégoire E and Labazée P (eds) Grands commerçants d'Afrique de l'Ouest: logiques et pratiques d'un groupe d'hommes d'affaires contemporains. Paris: Éditions Karthala, 101-123.

Egger PH, von Ehrlich M and Nelson DR. (2012) Migration and Trade. The World Economy 35: 216-241.

Ehrhart H, Le Goff M, Rocher E, et al. (2014) Does migration foster exports? Evidence from Africa. World Bank Policy Research Working Paper No. 6739. (accessed 2 March 2017).

Ellis S and MacGaffey J. (1997) Le commerce international informel en Afrique subsaharienne. Quelques problèmes méthodologiques et conceptuels. Cahiers d'Études Africaines 37: 11-37.

Feenstra RC and Hanson GH. (2004) Intermediaries in Entrepot Trade: Hong Kong ReExports of Chinese Goods. Journal of Economics \& Management Strategy 13: 3-35.

Felbermayr GJ and Toubal F. (2012) Revisiting the Trade-Migration Nexus: Evidence from New OECD Data. World Development 40: 928-937.

Freeman C (1997) Reinventing higglering across transnational zones. In: Springfield CL (ed) Daughters of Caliban: Caribbean women in the twentieth century. Bloomington: Indiana University Press, 68-95.

GCIM. (2005) Migration in an interconnected world: new directions for action, Geneva: Global Commission on International Migration.

Gillespie S. (2001) South-South transfer: a study of Sino-African exchanges, New York: Routledge.

Gould DM. (1994) Immigrant Links to the Home Country: Empirical Implications for U.S. Bilateral Trade Flows. The Review of Economics and Statistics 76: 302-316.

H\&N (this issue) Organised Informality and Suitcase Trading in the Pearl River Delta Region.

Hart K. (2005) The hit man's dilemma. Or, business, personal and impersonal, Chicago: Prickly Paradigm.

Hatzigeorgiou A and Lodefalk M. (2015) Trade, migration and integration-Evidence and Policy Implications. The World Economy 38: 2013-2048.

Haugen HØ. (2011) Chinese Exports to Africa: Competition, Complementarity and Cooperation between Micro-Level Actors. Forum for Development Studies 38: 157 176.

Haugen HØ. (2017) Petty commodities, serious business: the governance of fashion jewellery chains between China and Ghana. Global Networks: online first.

Hevi EJ. (1963) An African Student in China, London: Pall Mall Press.

Hill P. (1966) Landlords and brokers: a West African trading system (with a note on Kumasi butchers). Cahiers d'études africaines 6: 349-366. 
Holtom P. (2006) Shuttle trade and new border regimes. Russian Regional Perspectives Journal 1: 1-7.

Holzlehner T. (2008) Weaving shuttles and ginseng roots: Commodity flows and migration in a borderland of the Russian Far East. http://escholarship.org/uc/item/5r96h3sb (accessed 04.10.2016).

Humphrey C. (1999) Traders, "disorder", and citizenship regimes in provincial Russia. In: Burawoy M and Verdery K (eds) Uncertain transition: ethnographies of change in the postsocialist world. Lanham, Md.: Rowman \& Littlefield.

Iglicka K. (2001) Shuttling from the former Soviet Union to Poland: From 'primitive mobility' to migration. Journal of Ethnic and Migration Studies 27: 505-518.

Iwanowsky M. (2014) The Role of Ethnic Networks in Africa: Evidence from Cross-Country Trade. http://sites.bu.edu/neudc/files/2014/10/paper_213.pdf (accessed 04.10.2016).

K. (this issue) Between Border and Bazaar: Central Asia's Informal Economy.

Karagöz K. (2016) Migration-trade nexus revisited: Empirical evidence from Turkish emigrants in OECD countries. Theoretical and Applied Economics 22: 127-142.

Konstantinov Y. (1996) Patterns of reinterpretation: trader-tourism in the Balkans (Bulgaria) as a picaresque metaphorical enactment of post-totalitarianism. American Ethnologist 23: 762-782.

Konstantinov Y, Kressel GM and Thuen T. (1998) Outclassed by former outcasts: Petty trading in Varna. American Ethnologist 25: 729-745.

Launay R. (1979) Landlords, Hosts, and Strangers among the Dyula. Ethnology 18: 71-83.

Le Bail H. (2009) Foreign Migration to China's City-Markets: the Case of African Merchants. Asie Visions. Paris: Centre Asie Ifri.

Li Z, Ma LJC and Xue D. (2009) An African Enclave in China: The Making of a New Transnational Urban Space. Eurasian Geography and Economics 50: 699-719.

Liang Y. (2013) 在广州的非洲裔移民行为的因果机制: 累积因果视野下的移民行为研究 (The causal mechanisms for African migration to Guangzhou: Research on immigration behavior in a cumulative causation perspective). 社会学研究 (Sociological research) 1: 134-159.

Lin X and Yang X. (2017) From human capital externality to entrepreneurial aspiration: Revisiting the migration-trade linkage. Journal of World Business.

Liu L, Wang KY and Yip TL. (2013) Development of a container port system in Pearl River Delta: path to multi-gateway ports. Journal of Transport Geography 28: 30-38.

Lyons M, Brown A and Li Z. (2008) The "third tier" of globalization: African traders in Guangzhou. City: analysis of urban trends, culture, theory, policy, action 12: 196-206.

MacGaffey J and Bazenguissa-Ganga R. (2000) Congo-Paris: Transnational traders on the margins of the law, Oxford: James Currey.

Mathews G. (2016) African Logistics Agents and Middlemen as Cultural Brokers in Guangzhou. Journal of Current Chinese Affairs 44: 117-144.

Meagher K. (2003) A back door to globalisation? Structural adjustment, globalisation \& transborder trade in West Africa. Review of African Political Economy 30: 57-75.

Meagher K. (2010) Identity economics. Social networks \& the informal economy in Nigeria, Suffolk: James Currey.

Ministry of Public Security (2012) Exit and Entry Administration Law of the People's Republic of China. http://www.mps.gov.cn/n16/n84147/n84196/3837042.html (accessed 30 January 2015).

Mohan, G., et al. (2014). Chinese migrants and africa's development: new imperialists or agents of change?, London: Zed Books.

Morokvasic M. (2004) 'Settled in Mobility': Engendering Post-Wall Migration in Europe. Feminist Review: 7-25. 
National Bureau of Statistics of China. (2016) China Statistical Yearbook 2016, Beijing: China Statistics Press.

Pellow D. (2002) Landlords and lodgers: Socio-spatial organization in an Accra community, Westport: Praeger.

Peraldi M. (1999) Marseille : réseaux migrants transfrontaliers, place marchande et économie de bazar. Cultures \& Conflits 33-34: 51-67.

Ping Q. (2014) 广州市副市长: 说广州有几十万非洲人是误解 (The vice mayor of Guangzhou says hundres of thousands of Africans is a misunderstanding). Southern Metropolis Daily. Guangzhou: The Nanfang Group.

Port Strategy. (2011) Agencies ordered out of Nigerian ports. Available at: http://www.portstrategy.com/news101/world/africa/agencies-ordered-out-of-nigerianports (accessed 10.03.2017).

R. (this issue) Cross-border trade and "the market" between Xinjiang (China) and Pakistan.

Rauch JE and Trindade V. (2002) Ethnic Chinese networks in international trade. Review of Economics and Statistics 84: 116-130.

Ribeiro GL. (2009) Non-hegemonic globalizations. Anthropological Theory 9: 297-329.

Rubbers B. (2009) 'We, the Congolese, we cannot trust each other'. Trust, norms and relations among traders in Katanga, Democratic Republic of Congo. The British Journal of Sociology 60: 623-642.

Sit V. (1998) Hong Kong's "Transferred" Industrialization and Industrial Geography. Asian Survey 38: 880-904.

Snow P. (1988) The star raft: China's encounter with Africa, London: Weidenfeld and Nicolson.

Tsing A (2009) Supply Chains and the Human Condition. Rethinking Marxism 21(2): 148176.

Ulysse GA. (2007) Downtown ladies: informal commercial importers, a Haitian anthropologist, and self-making in Jamaica, Chicago: University of Chicago Press.

UN Comtrade. (2016) International trade statistics database. Available at: www.comtrade.un.org (accessed 10.03.2017).

UNDP. (2017) Human Development Report 2016, New York: United Nations Development Programme.

Verne J. (2012) Living Translocality: Space, Culture and Economy in Contemporary Swahili Trade, PhD Dissertation. Wiesbaden: Franz Steiner Verlag

World Bank. (2017) Container Port Traffic Database. http://data.worldbank.org/indicator/IS.SHP.GOOD.TU (accessed 10.03.2017).

Yan, S. (2012) "Nigerian's death sparks demo." People's Daily. http://www.globaltimes.cn/content/716028.shtml (accessed 31.08.2012).

Yükseker D. (2007) Shuttling goods, weaving consumer tastes: Informal trade between Turkey and Russia. International Journal of Urban and Regional Research 31: 60-72.

Zhang Ya. (2015) Guangzhou to recapture former glory as shipping hub. China Daily. http://www.chinadaily.com.cn/regional/2015-04/03/content_19994753.htm (accessed 15.01.2017).

Zhou M. (2004) Revisiting Ethnic Entrepreneurship: Convergencies, Controversies, and Conceptual Advancements. International Migration Review 38: 1040-1074. 